\title{
A new fossil species of Phlebotominae sand fly from Miocene amber of Chiapas, Mexico (Diptera: Psychodidae)
}

\author{
Sergio Ibáñez-Bernal • Mónica Solórzano Kraemer • \\ Frauke Stebner $\cdot$ Rüdiger Wagner
}

Received: 3 April 2013/Accepted: 21 June 2013/Published online: 23 July 2013

(C) The Author(s) 2013. This article is published with open access at Springerlink.com

\begin{abstract}
The male of Pintomyia (Pifanomyia) bolontikui sp. nov., from the Miocene Mexican amber deposits of Simojovel, Chiapas, is described. This is the second fossil phlebotomine sand fly described from Mexico. Morphological differences between fossil and extant species of American phlebotomine sand flies are discussed.
\end{abstract}

Keywords Mexican amber $\cdot$ Phlebotomine $\cdot$ Pintomyia

Kurzfassung Pintomyia (Pifanomyia) bolontikui sp. nov. aus dem Miozänen Mexikanischen Bernstein von Simojovel, Chiapas wird beschrieben. Dies ist die zweite beschriebene fossile Phlebotomine aus Mexiko. Morphologische Unterschiede zwischen fossilen und rezenten Arten der amerikanischen Phlebotominae werden diskutiert.

Schlüsselwörter Mexikanischer Bernstein .

Phlebotomine $\cdot$ Pintomyia

S. Ibáñez-Bernal $(\bowtie)$

Instituto de Ecología, A. C. Red Ambiente y Sustentabilidad,

Antigua carretera a Coatepec No. 351 El Haya, 91070 Xalapa,

Veracruz, México

e-mail: sergio.ibanez@inecol.edu.mx

\section{S. Kraemer · F. Stebner}

Steinmann-Institut für Geologie, Mineralogie und Paläontologie Rheinische Friedrich-Wilhelms-Universität Bonn, Nussallee 8, 53115 Bonn, Germany

\section{S. Kraemer}

Senckenberg Forschungsinstitut und Naturmuseum, Senckenberganlage 25, 60325 Frankfurt am Main, Germany

R. Wagner

FB 18 Naturwissenschaften, Institut für Biologie, Heinrich-Plett-Straße 40, 34132 Kassel, Germany

\section{Introduction}

Phlebotominae is one of the six subfamilies of Psychodidae, with more than 800 species described worldwide (Wagner 2009; Curler and Moulton 2012). Due to their medical and veterinary importance, it is the best studied group of psychodids, as their females are hematophagous and involved in the transmission of pathogens, principally those that produce all clinical types of leishmaniasis (Young and Arias 1991). Nevertheless, their taxonomy is controversial and much discussed. Rohdendorf (1964) as well as Abonnenc (1976) and Williams (1993) gave them family rank, whereas they were treated as a subfamily of Psychodidae including six genera of Phlebotminae according to Lewis et al. (1977) and Young and Duncan (1994), as a subfamily including 24 genera according to Artemiev (1991), and as a subfamily including 31 genera according to Galati (2003).

Psychodidae are known from the Lower Jurassic (Ansorge 1994; Krzeminski 2003) and probably from the upper Triassic (Blagoderov et al. 2007).

The oldest records of phlebotomine-like species from amber are from the Lower Cretaceous deposits of France (Perrichot et al. 2007), Spain (Declòs et al. 2007) and Lebanon (Azar et al. 1999), although the placement of some of these species into the Phlebotominae still is a matter of debate (Lukashevich 2003). Furthermore, two species of Phlebotomites from Lebanese amber (Hennig 1972) and Palaeomyia burmitis from Burmese amber (Poinar 2004) show evidence of blood-sucking habits that, in addition to other morphologic characteristics, support their inclusion in Phlebotominae.

From the Eocene, two genera, Phlebotomiella and Sergentomyia, are known from Baltic amber (Andrade Filho and Brazil 2003) and one more from Indian amber 

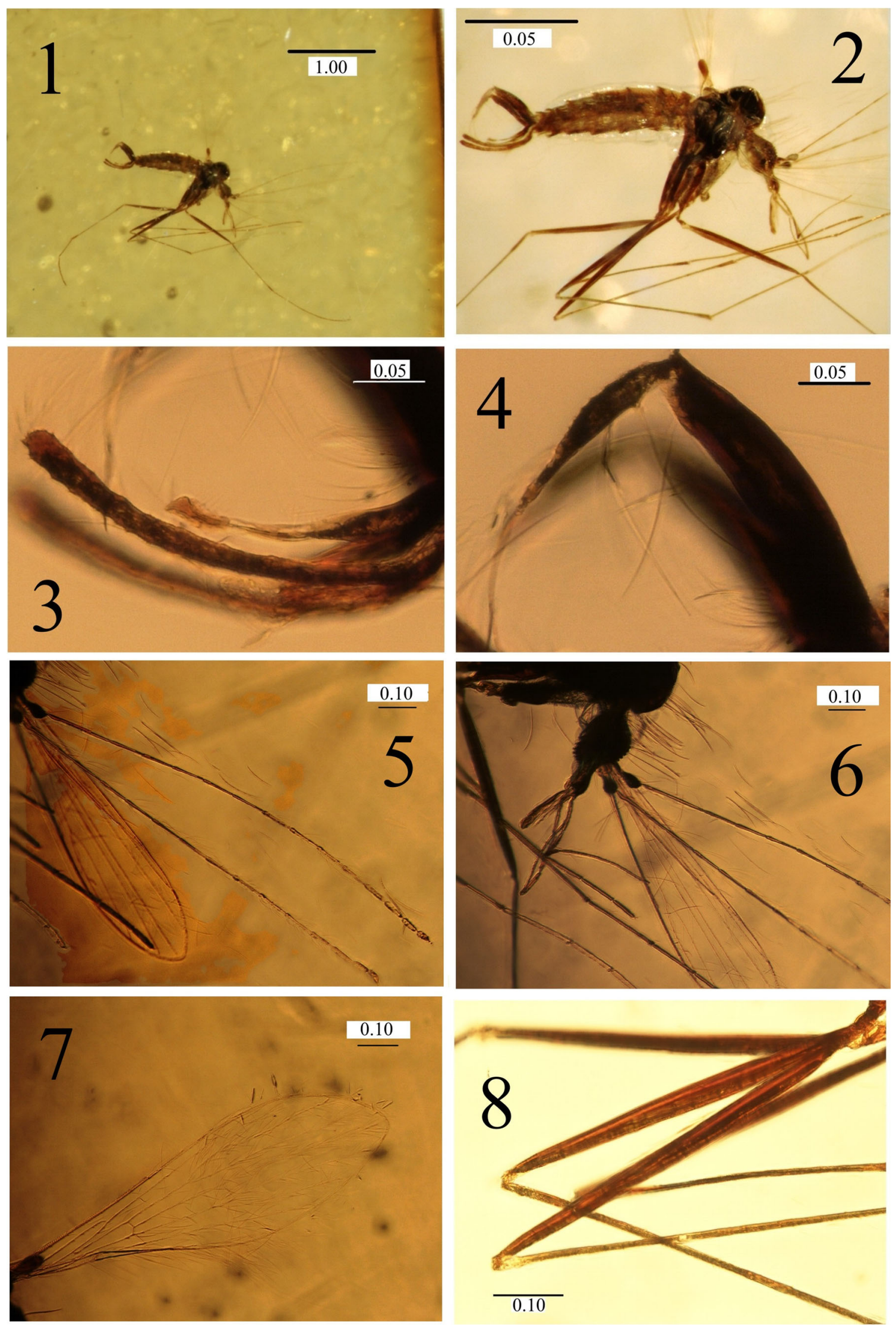
4 Fig. 1 Photographs of Pintomyia (Pintomyia) bolontikui sp. nov. (holotype, male, Mx 351.3). 1 General view; 2 body close-up; 3 detail of paramere, lateral lobe and cercus; $\mathbf{4}$ detail of gonopod; $\mathbf{5}$ antennae; $\mathbf{6}$ head and its appendages; $\mathbf{7}$ wing; 8 detail of hind femora. Scales in millimeters

described as Phlebotoiella by Solórzano Kraemer and Wagner (2009).

From the New World, 16 fossil species are described to date from the Miocene Dominican and Mexican amber deposits. These correspond to the genus Lutzomyia França (sensu Young and Duncan 1994) or to genera Micropygomyia Barretto (3 spp.), Pintomyia Costa Lima (12 spp.), and Psathyromyia Barretto (1 sp.) (sensu Galati 2003), (Poinar 2008; Andrade Filho et al. 2009a; Andrade Filho et al. 2009b).

From the Mexican amber deposit of Simojovel de Allende, Chiapas, which is dated to the Miocene age (20 Ma) (Solórzano Kraemer 2007), only the phlebotomine sand fly Micropygomyia (Sauromyia) paterna Quate, 1963 sensu Galati (2003), described as Phlebotomus paternus, has been recorded. In this report the second species of phlebotomine sand fly from the Simojovel amber is described based on morphological characteristics of a male specimen.

\section{Materials and methods}

The piece of amber containing the specimen was polished to form a cube, measuring $7.5 \times 5.2$ (principal surface) $\times 3.3 \mathrm{~mm}$ (proof). The specimen was examined using a Nikon Eclipse 50i microscope. Measurements were obtained with an ocular micrometer and are given in millimeters. Drawings were rendered with the aid of a Nikon Y-IDT drawing tube and digitally processed with Corel Photo Paint X3 (Version 13). Microphotographs were captured with a Nikon Digital Sight DS-2Mv camera using NIS-Elements F 3.2 and later edited for clarity using Helicon Focus v. 4.75.

Morphological terminology is in accordance with Young and Duncan (1994) and Galati (2003). We follow the phylogenetic classification proposed by Galati (1995, 2003), but the equivalent nomenclature according to Young and Duncan (1994) is included for reference. Abbreviations for genera and subgenera names follow the proposed system of Marcondes (2007).

\section{Systematic palaeontology}

Family Psychodidae Newman

Psychodidae Newman 1834: 388; 1835, 185-254 (as Psychodites).
Subfamily Phlebotominae Rondani

Phlebotominae Rondani, 1840: 10, 12 (as Flebotomidae).

Tribe Phlebotomini Rondani

Phlebotomini Rondani, 1840: 12.

Subtribe Lutzomyiina Abonnenc and Leger

Lutzomyiinae Abonnenc and Leger, 1976: 357 (as subfamily of Phlebotomidae, as they considered it a distinct family separated from Psychodidae). Type genus: Lutzomyia França, 1921.

Lutzomyiina Abonnenc and Leger: as subtribe sensu Galati 2003, 34.

Genus Pintomyia Costa Lima

Phlebotomus, subgenus Pintomyia Costa Lima, 1932: 44. Type species: Phlebotomus fischeri Pinto.

Phlebotomus, species group triacanthus, series fischeri: Fairchild, 1955: 194.

Lutzomyia, subgenus Pintomyia Costa Lima: Barretto, 1962: 92;

Lutzomyia species group Verrucarum Theodor, 1965: 183; Lewis et al., 1977: 325; Martins et al., 1978: 124 (in part); Young and Duncan, 1994: 171.

Pintomyia Costa Lima: Forattini, 1971: 103 (in part); Forattini, 1973: 497 (in part); Artemiev, 1991: 73; Galati, 2003: 37.

Subgenus Pifanomyia Ortiz and Scorza

(=species group Verrucarum Theodor, sensu Young and Duncan 1994)

Pifanomyia Ortiz and Scorza, 1963. Type species: Flebotomus serranus Damasceno and Arouck; Galati, 2003: 37.

Pintomyia (Pifanomyia) bolontikui sp. nov

(Figs. 1, 2).

\section{Diagnosis}

The specimen can be clearly distinguished from other Pintomyia by: palpus with segment 5 larger than segments $3+4$, hind femur without longitudinal row of short spines, male terminalia with a patch of persistent setae on basal half, gonostylus with subterminal setae and four large spiniform setae inserted at different levels, paramere long, simple, and truncate.

\section{Description}

Holotype, male, Mx 351.3. Body length $1.55 \mathrm{~mm}$, coloration dark brown, with mesonotum and pleura concolours, abdomen slightly paler. 


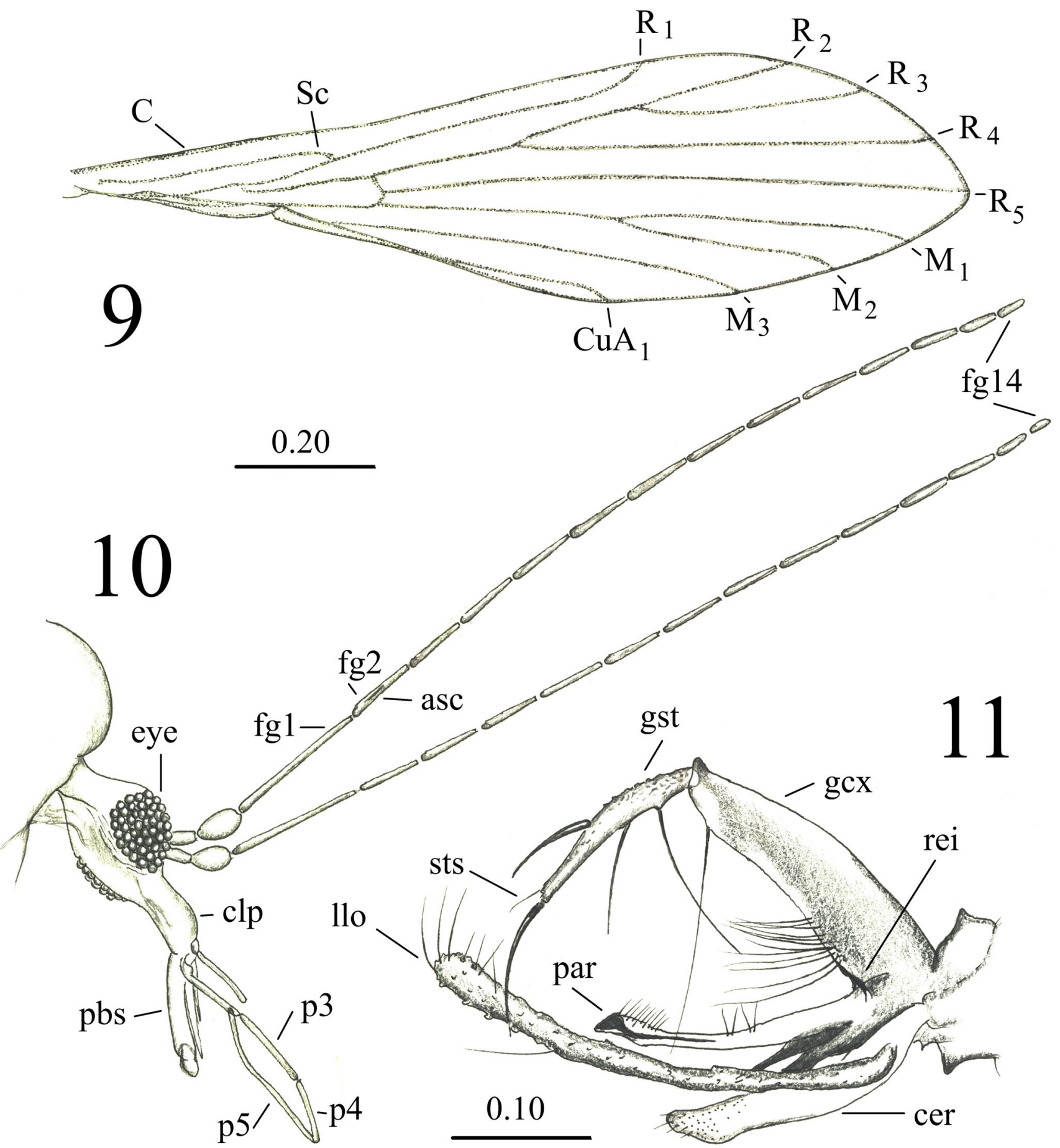

Fig. 2 Drawings of Pintomyia (Pintomyia) bolontikui sp. nov. (holotype, male, Mx 351.3); 9 wing; 10 head and appendages; 11 male terminalia, lateral. Abbreviators: asc ascoid, der cercus, $c l p$ clypeus, eye eye, $f g 1-f g 2, f g 14$ flagellomeres 1,2 , and 14 ,

Head oblique extended forwards and laid on its side, length from vertex to apex of clypeus $0.325 \mathrm{~mm}$, clypeus $0.11 \mathrm{~mm}$, length of proboscis $0.175 \mathrm{~mm}$; palpus length: $0.635 \mathrm{~mm}$; palpomere proportions: 1.0: 4.0: 5.0: 3.6: 11.8 (in mm: 0.025: 0.1: 0.125: 0.09: 0.295); palpus segment five respectively, gcx gonocoxite, gst gonostylus, llo lateral lobe, par paramere, $p b s$ proboscis, $p 3-5$ palpal segments 3,4 , and 5, respectively, rei reinforcement of gonocoxite, sts subterminal seta. Figs. 9 and $\mathbf{1 0}$ same scale. Scales in millimeters

longer than the sum of $3+4$, but shorter than $2+3+4$. Labrum-epipharynx reaching middle of palpomere 3 and nearly the apex of flagellomere 1 . Antenna with flagellomere 1 as long as 1.17 the length of labium, scape $(0.045 \mathrm{~mm})$ nearly as long as pedicel $(0.055 \mathrm{~mm})$, flagellum 
with 14 flagellomeres with a total length of $1.375 \mathrm{~mm}$; length of flagellomeres 1-3: 0.205: 0.112: $0.102 \mathrm{~mm}$. Ascoids difficult to recognize, simple, and reaching the middle of the flagellomere. Cervical sensilla not seen.

Thorax dark and somewhat collapsed, obscuring external characters. Legs without special characters. Front leg lengths: coxa: $0.275 \mathrm{~mm}$, trochanter: $0.030 \mathrm{~mm}$, femur: $0.620 \mathrm{~mm}$, tibia: $0.53 \mathrm{~mm}$, tarsomere $1: 0.325 \mathrm{~mm}$, tarsomere 2: $0.190 \mathrm{~mm}$, tarsomere 3: $0.130 \mathrm{~mm}$, tarsomere 4: $0.115 \mathrm{~mm}$, tarsomere 5: $0.080 \mathrm{~mm}$; midleg lengths: coxa: $0.270 \mathrm{~mm}$, trochanter: $0.065 \mathrm{~mm}$, femur: $0.550 \mathrm{~mm}$, tibia: $0.690 \mathrm{~mm}$, tarsomere 1: $0.410 \mathrm{~mm}$, tarsomere 2: $0.205 \mathrm{~mm}$, tarsomere 3: $0.135 \mathrm{~mm}$, tarsomere 4: $0.115 \mathrm{~mm}$, tarsomere 5: $0.080 \mathrm{~mm}$; hindleg lengths: coxa: $0.270 \mathrm{~mm}$, trochanter: $0.080 \mathrm{~mm}$, femur: $0.645 \mathrm{~mm}$, tibia: $0.880 \mathrm{~mm}$, tarsomere 1: $\quad 0.485 \mathrm{~mm}$, tarsomere 2: $0.225 \mathrm{~mm}$, tarsomere 3 : $0.145 \mathrm{~mm}$, tarsomere 4: $0.130 \mathrm{~mm}$, tarsomere 5: $0.085 \mathrm{~mm}$. Wing somewhat turned at base; length: $1.310 \mathrm{~mm}$, width: $0.365 \mathrm{~mm}$, relation length/width: $3.5 \mathrm{~mm}$; Sc not branched, ending in $R_{1}$; Rs four branched, all branches complete and ending on wing margin; $R_{1}(0.775 \mathrm{~mm})$ slightly shorter than $R_{5}(0.840 \mathrm{~mm})$, and $\operatorname{Rs}(0.187 \mathrm{~mm})$ shorter than $R_{2+3+4}$ $(0.220 \mathrm{~mm})$; vein $R_{2}(0.220 \mathrm{~mm})$ and $R_{3}(0.340 \mathrm{~mm})$ longer than $R_{2+3}(0.160 \mathrm{~mm}), R_{5}$ straight $(0.845 \mathrm{~mm})$, vein $M_{1+2}$ from level of vein $\mathrm{r}-\mathrm{m}$ to branch $(0.295 \mathrm{~mm})$ shorter than $M_{1}(0.490 \mathrm{~mm})$ and $M_{2}(0.395 \mathrm{~mm}), \mathrm{CuA}_{1}$ and $\mathrm{CuA}_{2}$ ending beyond level of $R_{2+3}$ and $R_{2+3+4}$ branches, respectively; wing values: $\alpha$ : $0.775 \mathrm{~mm}, \beta: 0.175 \mathrm{~mm}, \delta$ : $0.075 \mathrm{~mm}, \gamma: 0.225 \mathrm{~mm}$; wing ratio values: $\beta / \alpha: 0.225 \mathrm{~mm}$, $\gamma / \alpha: 0.290 \mathrm{~mm}, \delta / \beta: 0.428 \mathrm{~mm}, \beta / \gamma: 0.777 \mathrm{~mm}$.

Abdomen extended, seven pregenital segments visible without special characters; terminalia with gonostylus $(0.135 \mathrm{~mm})$ as long as half the length of gonocoxite $(0.265 \mathrm{~mm})$, bearing one subterminal seta and four spiniform setae all arranged at different levels, one apical, which is long and thick, one preapical as thick but slightly shorter than the apical originating at middle of the distance between the apical and the prebasal spiniform setae, one prebasal spiniform seta thin and as long as the preapical originating at middle between basal and preapical spiniform setae, and one basal spiniform seta, which is the longest, as thin as the prebasal one, originating at middle between the base of gonostylus and the origin of the prebasal spiniform seta; gonocoxite with sclerotized reinforcement at base and with long, evenly spaced, perennial setae over its basal half, and longer preapical setae on ventral margin; paramere $(0.215 \mathrm{~mm})$ shorter than gonocoxite, simple, without dorsal protuberances, but with a broad, truncate, apparently reinforced apex, with a group of short ventral pilosity on the apical fifth, and a ventral group of few larger setae at middle; lateral lobes very long $(0.320 \mathrm{~mm})$ and slender $(0.015 \mathrm{~mm}$ at middle $)$; ejaculatory apodeme and pump not seen, but filaments with unmodified apex; cercus long $(0.175 \mathrm{~mm})$ reaching about middle of lateral lobes.

\section{Etymology}

From the Mayan language, Bolontikú, the generic name given to the nine gods of the underworld, according to the Mayan cosmogony myth as expressed in the Chilam Balam of Chumayel (Médiz Bolio, A. [Transl.] 1985).

\section{Material examined}

Holotype, male: Early Middle Miocene age amber from Simojovel, Chiapas, Mexico. The specimen belongs to the collection of the Staatliches Museum für Naturkunde, Schloss Rosenstein, Stuttgart, Germany (SMNS). The inventory number of the specimen is Mx 351.3

\section{Remarks}

The new species described here shares with Trichopygomyia Barretto the lack of a condensed basal tuft on the gonocoxite but the presence of numerous spaced persistent setae, the gonostylus with four spiniform setae inserted at different levels and subterminal setae present, and the lateral lobe longer than the gonocoxite, but it differs in having a simple paramere in contrast to the complex bifurcate or trifurcate paramere of that group. The new species is included in the genus Pintomyia because of: the antenna with flagellomere 1 usually longer than 0.5 the length of head, flagellomeres with simple ascoids, gonostylus with one apical spiniform seta and with subterminal setae, paramere simple, lateral lobe narrower than gonocoxite with rounded apex, and gonocoxite with sclerotized reinforcement at the base. Further, the hind femur does not have spines in the subgenus Pifanomyia. Galati (2003) recognized seven series of species of this subgenus. Pintomyia (Pifanomyia) bolontikui sp. nov. probably corresponds to the series townsendi, because the gonocoxite has a patch of setae on the basal half of the structure and gonostylus with four spiniform setae, the basal seta isolated. However, characteristics of the ejaculatory ducts, sensorial papillae of the flagellomeres, and coloration of the thoracic sclerites were all impossible to observe.

As compared with the extant species of the Pintomyia (Pifanomyia) series townsendi, Pi. (Pif.) bolontikui sp. nov. is similar to Pi. spinicrassa (Morales et al. 1969), by the apical spiniform setae of the gonostylus, which is evidently thicker than the other three, but differs in not having the notch in the preapical dorsal margin of the apical setae, by 
having a more dispersed patch of setae in the gonocoxite, and a considerably longer lateral lobe as compared with the paramere and gonocoxite lengths. Pintomyia nadiae (Feliciangeli, Arredondo, and Ward 1992), and Pi. amilcari (Arredondo 1984), differ by the presence of a dorsal hump in the basal third of the paramere. Pi. torvida (Young, Morales, and Ferro, in: Young and Duncan 1994), differs in the strongly arched paramere and the condensed basal tuft on the gonocoxite. Pi. longiflocosa (Osorno-Mesa et al. 1970), Pi. youngi (Feliciangeli and Murillo, in: Murillo and Zeledón 1985), Pi. quasitownsendi (Osorno, Osorno-Mesa, and Morales-Alarcon 1972), Pi. townsendi (Ortiz 1959), and Pi. sauroida (Osorno-Mesa, Morales-Alarcon, and Osorno 1972), differ in the condensed basal tuft on the gonocoxite and the position of the spiniform setae of the gonostylus, which are equally separated from each other in Pi. bolontikui. An overview of Recent Pintomyia (Pifanomyia) can be found in Young and Duncan (1994), Cazorla (1995) and Galati (2003).

To date, 16 fossil sand fly species have been described from the New World (Andrade Filho et al. 2009a; Andrade Filho et al. 2009b), almost all from the Miocene Dominican amber deposits with the exception of Micropygomyia paterna (Quate 1963) from Mexican amber. Of these, 12 species belong to the genus Pintomyia (sensu Galati 2003), with 6 of those having 4 spiniform setae on the gonostylus, like the new species described in the present work. Pintomyia falcaorum Brazil and Andrade Filho, 2002, Pi. paleotownsendi Andrade Filho, Falcão, Galati, and Brazil, 2006, and Pi. paleotrichia Andrade Filho, Brazil, Falcão, and Galati, 2007, differ from Pi. bolontikui sp. nov. by having a spiniform seta in the dorsal margin of the basal third of the paramere. Pintomyia dominicana Andrade Filho, Galati, and Brazil, 2008, differs from the new species by having two basal spiniform setae on the surstylus originating at the same level, and a long, thin and arched paramere. Pi. killickorum Andrade Filho, Falcão, and Brazil, 2004, has a dorsal lobe in the paramere, and Pi. filipalpis Peñalver, and Grimaldi, 2005, has an elbowed paramere and a different distribution of the spiniform setae on the gonostylus.

Acknowledgments The authors would like to thank Dr. Günter Bechly from the Staatliches Museum für Naturkunde Stuttgart for the loan of the specimen and Dr. Alan Lord for grammar correction. S. I-B. was supported by the project INECOL-10816. This research was also possible with a postdoctoral fellowship to M.M.S.K, no. SO894/3-1, from the German Research Foundation (DFG).

Open Access This article is distributed under the terms of the Creative Commons Attribution License which permits any use, distribution, and reproduction in any medium, provided the original author(s) and the source are credited.

\section{References}

Abonnenc, E., and N. Leger. 1976. Rectificatif à la note: "Sur une classification rationelle des Diptères Phlebotomidae". Cahiers ORSTOM.Série Entomologie Médicale et Parasitologie 14(4): $1-357$.

Andrade Filho, J.D., and R.P. Brazil. 2003. Relationships of new world Phlebotomine sand flies (Diptera: Psychodidae) based on fossil evidence. Memórias do Instituto Oswaldo Cruz 98(Suppl. 1): 145-149.

Andrade Filho, J.D., A.L. Falcão, E.A.B. Galati, and R.P. Brazil. 2006. Pintomyia (Pifanomyia) paleotowsendi, a new sand fly from the Miocene amber of Dominican Republic (Diptera: Psychodidae: Phlebotominae). Memmórias de Instituto Oswaldo Cruz 101(Suppl. 2): 57-58.

Andrade Filho, J.D., R.P. Brazil, A.L. Falcão, and E.A.B. Galati. 2007. Description of Pintomyia (Pifanomyia) paleotrichia, a Miocene period new species from the Dominican Republic (Diptera: Psychodidae: Phlebotominae). Memórias do Instituto Oswaldo Cruz 102: 901-903.

Andrade Filho, J.D., E.A.B. Galati, and R.P. Brazil. 2009a. Review of American fossil Phlebotominae (Diptera: Psychodidae) with a description of two new species. J Medical Entomol 46: 969-979.

Andrade Filho, J.D., P.C.L. Serra e Meira, C.C. Sanguinette, and R.P. Brazil. 2009b. Description of a new species, Pintomyia dissimilis nov. sp., a phlebotomine fossil from Dominican Republic amber (Diptera: Psychodidae: Phlebotominae). Parasites Vectors 2: $1-25$.

Ansorge, J. 1994. Tanyderidae and Psychodidae (Insecta: Diptera) from the lower Jurassic of Northeastern Germany. Palaontologische Zeitschrift 68: 199-210.

Arredondo, C.C. 1984. Phlebotominae de Venezuela: Lutzomyia amilcari sp. n. del Estado de Lara. Memorias do Instituto Oswaldo Cruz 79: 63-66.

Artemiev, N.M. 1991. A classification of the subfamily Phlebotominae. Parassitologia 33(Suppl. 1): 69-77.

Azar, D., A. Nel, M. Solignac, J.C. Paicheler, and F. Bouchet. 1999. New genera and species of psychodid flies from the lower Cretaceous amber of Lebanon. Paleontology 42: 1101-1136.

Barretto, M.P. 1962. Nova subgeneros de Lutzomyia França, 1924 (Psychodidae, subfamilia Phlebotominae). Revista do Instituto Medicina Tropicais 4: 91-100.

Blagoderov, V., D.A. Grimaldi, and N.C. Fraser. 2007. How time flies for flies: diverse Diptera from the Triassic of Virginia and early radiation of the order. American Museum Novitates 3572: 1-39.

Brazil, R.P., and Andrade Filho, J.D. 2002. Description of Pintomyia (Pifanomyia) falcaorum sp. n. (Diptera: Psychodidae: Phlebotominae), a Fossil Sand Fly from Dominican Amber. Memorias do Instituto Oswaldo Cruz 97: 501-503.

Cazorla, D. 1995. Revisión del grupo verrucarum Theodor, 1965 (Diptera: Psychodidae, Phlebotominae). Revista de Ecología Latinoamericana 3: 51-56.

Costa Lima, A. 1932. Sôbre os phlebotomos americanos (Diptera: Psychodidae). Memorias do Instituto Oswaldo Cruz 26: 15-69.

Curler, G.R., and J.K. Moulton. 2012. Phylogeny of psychodid subfamilies (Diptera: Psychodidae) inferred from nuclear DNA sequences with a review of morphological evidence for relationships. Systematic Entomology 37: 603-616.

Declòs, X., A. Arillo, E. Peñalver, E. Barrón, C. Soriano, R. López del Valle, E. Bermúdez, C. Corral, and V.M. Ortuño. 2007. Fossiliferous amber deposits from Cretaceous (Albian) of Spain. Comptes Rendus de l'Académie des Sciences-Series IIA-Earth and Planetary Science (Comptes Rendus Palevol) 6: 135-149. 
Fairchild, G.B. 1955. The relationships and classification of the Phlebotominae (Diptera, Psychodidae). Annals of the Entomological Society of America 48: 182-196.

Feliciangeli, M.D., C. Arredondo, and R.D. Ward. 1992. Phlebotomine sandflies in Venezuela: Review of the verrucarum species group (in part) of Lutzomyia (Diptera: Psychodidae) with description of a new species from Lara. Journal of Medical Entomology 29: 729-744.

Forattini, O.P. 1971. Sôbre a classificação da subfamilia Phlebotominae nas Americas (Diptera, Psychodidae). Papeis Avulsos 24: 93-111.

Forattini, O.P. 1973. Entomologia Medica. IV. Psychodidae. Leishmanioses. Bartonelose., São Paulo: Edgard Blucher.

Galati, E.A.B. 1995. Phylogenetic systematics of the Phlebotominae (Diptera: Psychodidae) with emphasis on American groups. Boletín de la Dirección de Malariología y Saneamiento Ambiental 35(1): 133-142.

Galati, E.A.B. 2003. 2. Morfologia e Taxonomia, 2.1. Classificação de Phlebotominae. In: Flebotomíneos do Brasil. Eds. E.F. Rangel and R. Lainson, 23-175. FIOCRUZ, Rio de Janeiro,

Hennig, W. 1972. Insektenfossilien aus der unteren Kreide IV. Psychodidae (Phlebotominae), mit einer kritischen Übersicht über das phylogenetische System der Familie und die bisher beschriebenen Fossilien (Diptera). Stuttgarter Beiträge zur Naturkunde A 241: 1-69.

Krzemiński, W. and Krzemińska, E. 2003. Triassic Diptera: descriptions, revisions and phylogenetic relations. Acta zoological cracoviensia 46 (Suppl.-Fossil Insects): 153-184.

Lewis, D.J., D.G. Young, G.B. Fairchild, and D.M. Minter. 1977. Proposals for a stable classification of the phlebotomine sandflies (Diptera: Psychodidae). Systematic Entomology 2: 319-332.

Lukashevich, E.D. and Mostovski, M,B. 2003. Hematophagous insects in the fossil record. Paleontological Journal 37: 153-161 (translated from Paleontologicheskii Zhurnal 2: 48-56).

Marcondes, C.B. 2007. A proposal of generic and subgeneric abbreviations for Phlebotomine sand flies (Diptera: Psychodidae: Phlebotominae) of the world. The Entomological News 118: 351-356.

Martins, A.V., P. Williams, and A.L. Falcão. 1978. American sandflies. Rio de Janeiro: Academia Brasileira de Ciencias.

Médiz Bolio, A. [Transl.] 1985. Libro de Chilam Balam de Chumayel. México, D. F: Serie Cien de México, Secretaría de Educación Pública.

Morales, A., E. Osorno-Mesa, F. Osorno, and P. Muñoz Hoyos. 1969. Phlebotominae de Colombia (Diptera, Psychodidae). V. Descripción de una nueva especie de Lutzomyia. Revista de la Academia Colombiana de Ciencias Exactas, Físicas y Naturales 13: 383-390.

Murillo, J., and R. Zeledón. 1985. Flebótomos de Costa Rica. Brenesia, $137 \mathrm{pp}$.

Newman, E. 1834. Attempted division of British insects into natural orders. Entomological Magazine 2: 379-431.

Newman, E. 1835. The grammar of entomology. Davis: F. Westley \& A.H. 304 pp.

Ortiz, I. 1959. Phlebotomus townsendi n. sp., interesante representante de los Psychodidae (Dipt.) de Rancho Grande, en el Estado de Aragua. Boletin Venezolano Laboratorio Clínico 4: 23-26.

Ortiz, I., and J.V. Scorza. 1963. Notas biológicas y taxonómicas sobre algunos Phlebotominae (Diptera, Psychodidae) de Rancho Grande, Venezuela. Acta Biológica Venezuelica 3: 341-361.
Osorno-Mesa, E., A. Morales-Alarcon, F. Osorno, and P. Muñoz Hoyos. 1970. Phlebotominae de Colombia (Diptera, Psychodidae). VI. Descripción de Lutzomyia longiflocosa n. sp. y Lutzomyia bifoliata n. sp. Boletín del Museo Natural de Historia Natural, Universidade Federal Minas Gerais 6: 1-18.

Osorno-Mesa, F., A. Morales-Alarcon, and F. Osorno. 1972. Phlebotominae de Colombia (Diptera, Psychodidae). VIII. Descripción de Lutzomyia saudoida sp. n. y Lutzomyia caprina sp. n. Revista Brasileira Biología 32: 433-441.

Osorno, F., E. Osorno-Mesa, and A. Morales-Alarcon. 1972. Phlebotominae de Colombia (Diptera, Psychodidae). VII. Descripción de Lutzomyia andina $\mathrm{n}$. sp. y Lutzomyia quasi-townsendi sp. $\mathrm{n}$. Boletín del Museo Natural de Historia Natural, Universidade Federal Minas Gerais 12: 1-21.

Perrichot, V., D. Néraudeau, A. Nel, and G. de Ploëg. 2007. A reassessment of the Cretaceous amber deposits from France and their palaeontological significance. African Invertebrates 48: 213-227.

Poinar Jr, G. 2004. Palaeomyia burmitis (Diptera: Phlebotomidae), a new genus and species of Cretaceous sand flies with evidence of blood-sucking habits. Proceedings of the Entomological Society of Washington 106: 598-605.

Poinar Jr, G. 2008. Lutzomyia adiketis sp. n. (Diptera: Phlebotomidae), a vector of Paleoleishmania neotropicum sp. n. (Kinetoplastida: Trypanosomatidae) in Dominican amber. Parasites \& Vectors 1(1): 1-22.

Quate, L.W. 1963. Fossil psychodidae in mexican amber, part 2 (Diptera: Insecta). Journal of Paleontology 37: 110-118.

Rohdendorf, B.B. 1964. The historical development of Diptera. Trudy Paleontological Institute 100: 1-312.

Rondani, C. 1840. Sopra una especie di insetto dittero. Donati: Memoria Prima per servire alla ditterologia Italiana.

Solórzano Kraemer, M.M. 2007. Systematic, palaeocology, and palaeobiogeography of the insect fauna from Mexican amber. Palaeontographica Abt. A 282: 1-133.

Solórzano Kraemer, M.M., and R. Wagner. 2009. The first psychodid (Diptera: Psychodidae: Phlebotominae) species from the lower Eocene amber of Vastan, Gujarat, India. Zootaxa 2152: 63-68.

Theodor, O. 1965. On the classification of American Phlebotominae. Jornal of Medical Entomology 2: 171-197.

Wagner, R. and Ibáñez-Bernal, S. 2009. Chapter 19. Psychodidae (sand flies, and moth flies or owl flies) In: Manual of Central American Diptera. Vol 1 Eds. Brown BV, Borkent A, Cumming JM, Wood DM, Zumbado M. 319-336. Ottawa, Ontario. Canada: NRC Research Press.

Williams, P. 1993. Relationships of Phlebotominae sand flies (Diptera). Memórias do Instituto Oswaldo Cruz 88: 177-183.

Young, D.G., and J.R. Arias. 1991. Phlebotomine sandflies in the Americas. Washington CD: Pan American Health Organization.

Young, D.G., and M.A. Duncan. 1994. Guide to the identification and geographic distribution of Lutzomyia sand flies in Mexico, The west Indies, central and south America (Diptera: Psychodidae). Memoirs of the American Entomological Institute 54: 1-881.

Young, D.G., and A. Morales. 1987. New species and records of phlebotomine sand flies from Colombia (Diptera: Psychodidae). Journal of Medical Entomology 24: 651-665. 